DOI https://doi.org/10.18551/rjoas.2018-02.26

\title{
THE EFFECT OF IMMERSION LENGTH IN PAPAYA LEAF SOLUTION (CARICA PAPAYA L.) TOWARD FERTILIZATION AND HATCHING OF IRIDESCENT SHARKS (PANGASIANODON HYPOPHTHALMUS S.)
}

\author{
Eka Septuresty Hartri ${ }^{\star}$ \\ Fisheries and Marine Biotechnology Program, University of Airlangga, Indonesia \\ Fadholi M. Rasyid, Sanoesi Ellana \\ Marine Sciences Program, University of Brawijaya, Indonesia \\ *E-mail: septuresty@yahoo.com
}

\begin{abstract}
Iridescent sharks is one kind of freshwater fish that is quite economical. However, the availability of the fish eggs is rather problematic due to the hatcheries, i.e. the adhesive nature of the eggs. Papaya leaves contain papain enzymes that can reduce the adhesive nature of eggs. The purpose of this study was to determine the effect of papaya leaf solution with different immersion period on the successful hatching of the iridescent sharks ( $P$. hypophthalmus). This study was conducted experimentally using a complete randomized design. There were five treatments, i.e. (K) 0 seconds, (A) 30 seconds, (B) 60 seconds, (C) 90 seconds, (D) 120 seconds, and (E) 150 seconds with three-time repetition. The result of this study shows that the best hatching (80.31\%) happens to the eggs immersed in papaya leaf solution for 60 seconds (treatment B).
\end{abstract}

\section{KEY WORDS}

Carica papaya, leaves, hatching, egss, Pangasianodon hypophthalmus.

Iridescent sharks (Pangasianodon hypophthalmus Sauvage) is one kind of freshwater fish that is quite economical. However, in Indonesia, this type of fish cannot be naturally spawned, yet artificial spawning has been done by practitioners and academics. The main factors that influence the spawning success are egg quality and sperm quality (Sutrisna, 2002). In order to meet the increasing demand of iridescent sharks, parent management must be done. Parent management aims to get quality seeds in a large number (Susanti and Mayudin, 2012); thus, to get good seeds, improving the egg quality is necessary (Yulfiperius et al., 2003).

Partosuwiryo and Irfan (2011) state that the eggs of iridesecnt sharks have adhesive properties. Therefore, some eggs may fail to hatch because the eggs are rather difficult to separate. This becomes one of the obstacles in the hatching process becuase the quality of water becomes disturbed when many egss fail to hatch. Thus, it is necessary to make efforts to overcome the adhesive nature of the eggs. One of the efforts is by using certain solution to remove the adhesive nature of the eggs (Slembrouck et al., 2005). Young papaya leaves produce much white sap that contains protein-breaking enzymes or proteolytic enzyme called papain. The protein-breaking enzymes will help to solve the problem, i.e. by immersing the eggs in the papaya leaf solution (Rahman, 2008).

This supports the statement of Slembrouck et al. (2005), that the adhesive eggs will stick to each other or on a substrate through the sticky mucous membrane and covers the entire surface. The adhesive nature of eggs inhibit the entry of oxygen that can inhibit the development of eggs and will affect the hatchability. The adhesive nature can be reduced by using natural ingredients such as papaya leaves. Papaya leaves contain enzymes, called papain, that can break down proteins or proteolytics. Papain has been proven capable of breaking down glucoprotein, which is part of the mucus layer of the eggs (Mustofa, 2009).

The purpose of this study was to determine the effect of different immersion periods in papaya leaf solution toward the success of fertilization and hatching of iridescent sharks $(P$. 
hypophthalmus). The study is expected to provide information about the effective immersion periods in papaya leaf solution to reduce the adhesive properties of eggs as to improve fertilization and hatching of iridescent sharks. The information will be benficial for cultivation technology, especially for breeding business of iridescent sharks ( $P$. hypophthalmus).

\section{METHODS OF RESEARCH}

The research was conducted at the Fish Research and Breeding Center of Sukamandi, Subang, West Java, from September to November 2013. The eggs of iridescent sharks were obtained from artificial spawning through HCG and OvaPrime hormone muting to stimulate gonad maturation in male and female parent fish. Stripping was done on the female whose gonad was mature enough. Male parent stripping was done to collect the sperms and female parent tripping was done to collect the eggs. Sperms and eggs are then collected for fertilization. After the fertilization, the eggs were immersed in papaya leaf solution; each treatment was given $15 \mathrm{ppt}$ dosage and the following tretament of immersion: (K) 0 second, (A) 30 second, (B) 60 second, (C) 90 second, (D) 120 seconds, and (E) 150 seconds. Furthermore, treated eggs were washed with distilled water to remove the rest of papaya leaf solution. Each treatment was spread on a tea strainer \pm 160 eggs and the treatment was repeated 3 times.

Each tea strainer contained \pm 160 eggs, and then transferred into a hatching incubation tub that had been prepared with a water temperature of $28^{\circ} \mathrm{C}$. Next, the stage of embryo development was observed. The percentage of fertilization and hatching rate was recorded. The rate of hatching was determined by counting the number of eggs that successfully hatched after 24 hours of incubation.

Data were analyzed using Completely Randomized Design. The effect of immersion time in papaya leaf solution (carica papaya I.) toward the fertilization and hatching of the iridescent sharks (Pangasianodon hypophthalmus s.) was examined using a diversity or Ftest. If the $F$ value is significantly different, then the smallest real difference (SRD) is done to determine the treatment that gives the best response as a significance rate of $5 \%$ and $1 \%$. To know the correlation between the treatment and the influenced results, a regression analysis is used-this analysis gives information about the influence of treatments.

\section{RESULTS OF STUDY}

Fertilization Rate. The length of immersion of the eggs of iridescent sharks (Pangasianodon hypophthalmus) in papaya leaf solution shows significantly different mean results on the fertilization rate. The data of the fertilization rate mean can be seen in Table 1.

Based on the mean, the length of immersion in papaya leaf solution gave very significant different effect $(P<0,01)$ to the fertilization rate of the eggs. Furthermore, the smallest real difference (SRD) was tested to see the different effect between treatments. The result of SRD test showed that D treatment $(96.42 \%)$, E treatment $(95.28 \%)$, and K $(94.75 \%$, immersion for 0 second) did not give significantly different effect on the fertilization rate. Treatment $A(99.02 \%)$ and $C(98.41 \%)$ had a significant effect on treatment $E$ and $K$, whereas treatment B (100\%) gave a significant different effect compared to all other treatments. To know the relationship pattern between the immersion length and the success of the fertilization, an orthogonal polynomial test was done. The test shows a relationship graph between the two variables in a quadratic equation os $Y=-0.0008 \times 2+0.110 x+$ 95.475 with R2 of 0.8184 . This indicates that the longer the immersion in papaya leaf solution, the lower the percentage of the fertilization rate. However, it can be seen that the optimal immersion time is for treatment $B$ (for 60 seconds) as the percentage of fertilization rate is $100 \%$. Figure 1 presents the result of the orthogonal polynomial test. 
Table 1 - The mean of the fertilization and hatching rate of the eggs of the iridescent sharks in different immersion lengths in papaya leaf solution

\begin{tabular}{ccc}
\hline Treatment & \multicolumn{2}{c}{ Variable } \\
\cline { 2 - 3 } & Fertilization Rate & Hatching Rate \\
\hline K (immersion 0 seconds) & $94.7 \pm 0.86^{\mathrm{a}}$ & $49.8 \pm 0.49^{\mathrm{a}}$ \\
\hline A (immersion 30 seconds) & $99 \pm 0.93^{\mathrm{a}}$ & $79.1 \pm 1^{\mathrm{a}}$ \\
\hline B (immersion 60 seconds) & $100 \pm 0^{\mathrm{a}}$ & $84.2 \pm 1.61^{\mathrm{b}}$ \\
\hline C (immersion 90 seconds) & $98.4 \pm 1.51^{\mathrm{ab}}$ & $63.3 \pm 6.48^{\mathrm{bc}}$ \\
\hline D (immersion 120 seconds) & $96.4 \pm 1.28^{\mathrm{ab}}$ & $56.54^{\mathrm{cd}}$ \\
\hline E (immersion 150 seconds) & $95.3 \pm 2.42^{\mathrm{b}}$ & $554.13^{\mathrm{d}}$ \\
\hline
\end{tabular}

Different superscripts shows a significant difference $(P<0.01)$.

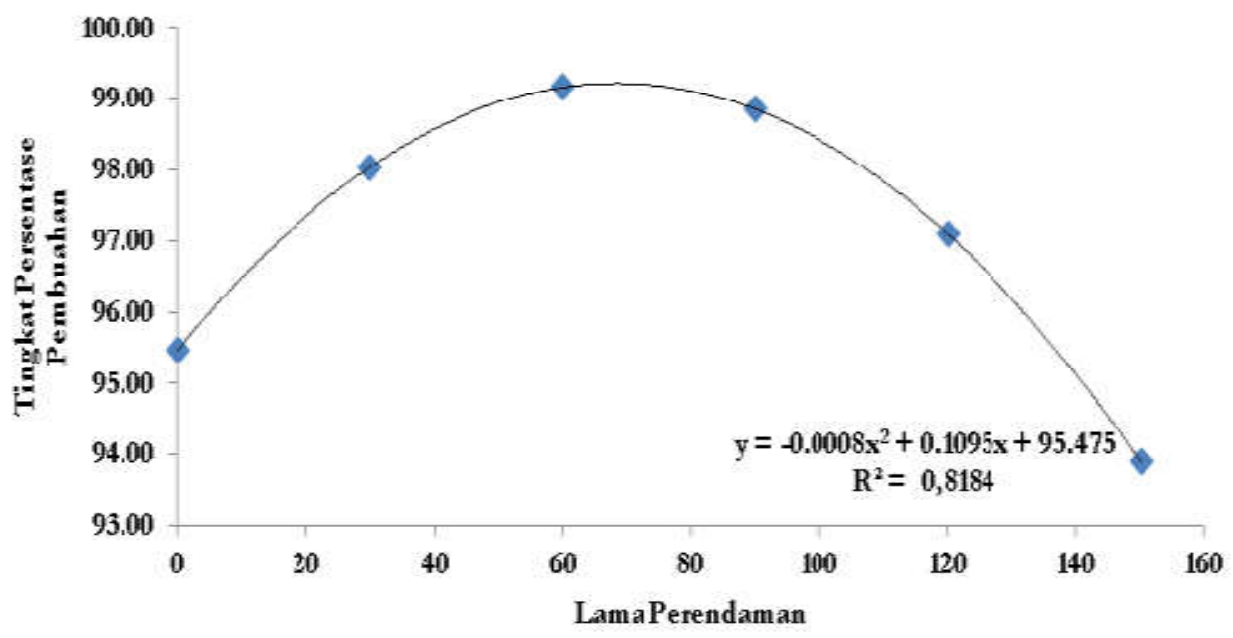

Figure 1 - The relationship of immersion length in papaya leaf solution with the fertilization rate (\%) of the eggs of iridescent sharks (P. hypophthalmus)

Hatching Rate. The length of immersion of the eggs of iridescent sharks (Pangasianodon hypophthalmus) in papaya leaf solution shows significantly different mean results on the hatching rate. The data of the hatching rate mean can be seen in Table 1.

Based on the mean, the length of immersion in papaya leaf solution gave very significant different effect $(P<0,01)$ to the hatching rate of the eggs. Furthermore, the smallest real difference (SRD) was tested to see the different effect between treatments. The result of SRD test showed that $E$ treatment $(55 \%)$ did not give significantly different effect compared to $\mathrm{K}$ treatment $(49.8 \%)$.

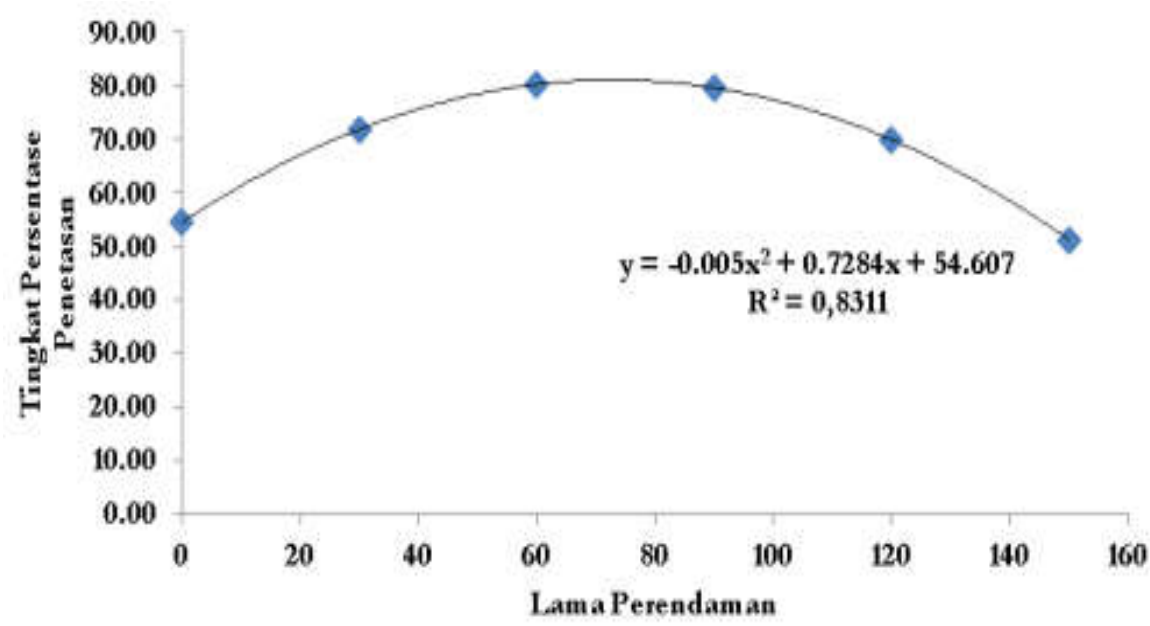

Figure 2 - The relationship of immersion length in papaya leaf solution with the hatching rate (\%) of the eggs of iridescent sharks ( $P$. hypophthalmus) 
Treatment $C(73.4 \%)$ was significantly different from treatment $D(66.5 \%)$ and from treatment A (79.1\%). Treatment B (84.2\%) gave a significant different effect compared to all other treatments. To know the relationship pattern between the immersion length and the success of the hatching, an orthogonal polynomial test was done. The test shows a relationship graph between the two variables in a quadratic equation os $Y Y=-0.005 \times 2+$ $0.7284 x+54.607$ with $\mathrm{R} 2$ of 0.8311 . This indicates that the longer the immersion in papaya leaf solution, the lower the percentage of the hatching rate. However, it can be seen that the optimal immersion time is for treatment $B$ (for 60 seconds) as the percentage of hatching rate is $84.2 \%$. Figure 2 presents the result of the orthogonal polynomial test.

\section{DISCUSSION OF RESULTS}

The results show that immersion in the papaya leaf solution significantly affects the percentage of fertilization and hatching rate of the iridescent sharks. This is shown in Figure 1 and 2. The percentage of fertilization and hatching rate has increased due to the immersion, indicating that the papaya leaf solution has the ability to reduce adhesive properties of the eggs of iridescent sharks, meaning that there is no egg death due to the lack of oxygen. The statement is supported by Woynorovich and Horvath (1980) suggesting that oxygen deprivation is one of the leading causes of egg and embryonic deaths. Yustina et al. (2003) adds the succes of the fertilization rate is seen from the nature and quality of the eggs. An unfavorable egg condition will interfere with the process of fertilization and eggs can also be damaged.

Papaya leaf solution containing a proteolytic enzyme known as papain can reduce adhesion of eggs of the iridescent sharks. Lukitasari (2004) in Setiaji (2009) states that papaya leaves contain such white sap, a protein-breaking enzyme or proteolytic enzyme, called papain. Mustofa (2009) adds that the presence of the proteolytic enzyme activity, i.e. papain, breaks down the glucoprotein, which is part of the mucus layer of the eggs. The broken down mucus layer reduces the adhesiveness of the eggs - the nature that causes the eggs to stick to other objects such as fungus and spores. In addition, the more egg pores open, the more oxygen they will get that will dinally help them to develop well. This process marks an increase in the rate of fertilization of the eggs of iridescent sharks. However, Figure 1 and 2 shows a decrease in the percentage of hatching due to the long immersion time in papaya leaf solution - this too long immersion will damage the eggs as the mucus layer eroded by the proteolytic enzyme.

\section{CONCLUSION}

The use of papaya leaf (C. papaya) solution brings a significant effect on the fertilization and hatching of the eggs of iridescent sharks ( $P$. hypophthalmus). The best immersion time in papaya leaf solution is for treatment B (60 seconds) as it brings a percentage of fertilization rate at $99.17 \%$ and hatching rate at $80.31 \%$.

\section{ACKNOWLEDGEMENTS}

The authors would like to thank the Airlangga University for giveng a chance to continue the study at the maritime and marine biotechnology program and to the Brawijaya University for the opportunity to study at the Undergraduate Degree of Fisheries and Marine Sciences.

\section{REFERENCES}

1. Ferdiansyah, V. 2005. Pemanfaatan kitosan dari cangkang udang sebagai matriks penyangga pada imobilisasi enzim protease. Unpublished Thesis. Jurusan Teknologi Hasil Pertanian. Fakultas Perikanan dan IImu Kelautan. Institut Pertanian. Bogor. 
2. Mustofa, G. A. 2009. Pemanfaatan getah pepaya (Carica papaya L.) kering sebagai sumber enzim proteolitik untuk meningkatkan derajat pembuahan dan derajat penetasan telur ikan mas (Cyprinus carpio L.). Jurnal Ilmu Kelautan Dan Perikanan. 19(1): 8-18.

3. Partosuwiryo, S. \& M. Irfan. 2011. Kiat Sukses Budidaya Ikan Patin. Yogyakarta: PT. Citra Aji Parama.

4. Rahman, F. M. 2008. Potensi antibakteri ekstrak daun pepaya pada ikan gurami yang diinf eksi bakteri Aeromonas hydrophila. Unpublished Thesis. Fakultas Kedokteran Hewan. Institut Pertanian Bogor.

5. Setiaji, A. 2009. Ef ektif itas ekstrak daun pepaya Carica papaya L. untuk pencegahan dan pengobatan ikan lele dumbo Clarias sp yang diidentifikasi bakteri Aeromonas hydrophilla. Unpublished Thesis. Departemen Budidaya Perairan Fakultas Perikanan dan IImu Kelautan. Institut Pertanian Bogor. Slembrouck, J., K. Oman, Maskur dan L. Merc. 2005. Petunjuk Teknis Pembenihan Ikan Patin Indonesia, Pangasius djambal. Jakarta: Karya Pratama.

6. Susanti R., \& A. Mayudin. 2012. Respons kematangan gonad dan sintasan induk ikan patin siam (Pangasius hypopthalmus) terhadap pakan dengan kandungan tepung cacing tanah berbeda. Jurnal Vokasi. 8(2): 110-120.

7. Sutrisna. 2002. Keragaman kualitas sperma ikan patin (pangasius hypophthalmus sauvage) pada bulan Oktober 2000 - Februari 2001. Unpublished Thesis. Jurusan Budidaya Perairan Fakultas Perikanan Dan IImu Kelautan. Institut Pertanian Bogor.

8. Woynarovich, E. \& L. Horvath. 1980. The artificial propagation of warmwater finfishes. A Manual for Extension. FAO. Fish Teach Pep.

9. Yulfiperius, Ing Mokoginta \& Dedi Jusadi. 2003. Pengaruh kadar vitamin e dalam pakan terhadap kualitas telur ikan patin (Pangasius hypopthalmus). Jurnal Iktiologi Indonesia. 3(1): 11-18.

10. Yustina, A \& Darmawati. 2003. Daya tetas dan laju pertumbuhan larva ikan hias Betta slendens di habitat buatan. Laboratorium Biologi, PMIPA, FKIP, Universitas Riau. Jurnal Natur Indonesia. 5(2): 129-132. 